logos_i_ethos_2_(33)_2012,s.179-201

Maciej Manikowski

\title{
Dialogiczność wiary: Tomáš Halík, Joseph Ratzinger i Józef Tischner
}

Katechizm Kościoła Katolickiego w sposób jakże wyraźny podkreśla dialogiczny charakter wiary, kiedy pisze: „Wiara jest aktem osobowym, wolną odpowiedzią człowieka na inicjatywę Boga, który się objawia"'. Jednakże ta wypowiedź Magisterium jest niejako wypadkową nauczania, jakie można znaleźć we wcześniejszych fragmentach Katechizmu.

Maciej Manikowski (ur. 1966) - absolwent filozofii Uniwersytetu Wrocławskiego, indywidualne studia teologiczne (podczas staży naukowych) w Rzymie, Leuven i Bochum, doktor habilitowany filozofii, adiunkt w Zakładzie Antropologii Filozoficznej Instytutu Filozofii Uniwersytetu Wrocławskiego. Naukowo zajmuje się filozofią dialogu, antropologią filozoficzną, filozofią rosyjską, teologią fundamentalną, teologią Trójcy Świętej oraz mistyką średniowieczną.

Wiara jest tam określana jako „adekwatna odpowiedź na zaproszenie Boga” (142), jako „osobowe przylgnięcie człowieka do Boga” (150) oraz „akt autentycznie ludzki” (154). Wszystkie te wypowiedzi podkreślają wyraźnie ludzki i osobowy wymiar wiary, ale również jej dialogiczny charakter poprzez podkreślenie dwóch elementów jako dwóch niezbywalnych brzegów połączonych przez most, jakim jest wiara: Boga i człowieka. Wiara jako akt osobowy pociąga za sobą konsekwencję w postaci poszanowania ludzkiej wolności. Katechizm odwołując się do soborowej deklaracji Dignitatis humanae powtarza, że „człowiek powinien dobrowolnie odpowiedzieć Bogu wiarą" (Dignitatis humanae, 10). Właśnie poprzez tę „dobrowolną odpowiedž” wiara staje się prawdziwie ludzka, osobowa.

1 Katechizm Kościoła Katolickiego, 166 (dalej: KKK). Cyt. na podstawie wydania: $K a-$ techizm Kościoła Katolickiego, Poznań 1994. 
Próbując określić wiarę jako dialog, jako spotkanie, podkreśla się jednocześnie jej relacyjny charakter ${ }^{2}$. Z jednej strony, można byłoby odwołać się tutaj do klasycznej literatury filozofii dialogu, w Polsce w sposób szczególny do prac ks. Józefa Tischnera, jak również do fenomenologicznej tradycji filozoficznej, w której warto wspomnieć choćby Bernharda Weltego, niemieckiego filozofa i teologa religii. Jest jednak jeszcze dwóch autorów, dla których dialogiczne rozumienie wiary jest czymś fundamentalnym, choć nie deklarują tego na gruncie systematycznej filozofii, lecz teologii czy teologicznej eseistyki, a są to Joseph Ratzinger i Tomáš Halík. W ich tekstach zauważyć można wyraźne odniesienia, choć niekiedy jedynie pośrednie, do myślenia dialogicznego, co jest zapewne wynikiem ogromnego oczytania w literaturze filozoficznej i teologicznej. Patrząc na te teksty, dostrzega się w nich specyficzne spotkanie trzech wielkich umysłów - krakowskiego filozofa spotkania, niemieckiego teologa, dzisiejszego papieża Benedykta XVI oraz czeskiego teologa, filozofa, socjologa i religioznawcy, jednego z duchowych przywódców Aksamitnej Rewolucji.

Próbując określić wiarę jako dialog czy spotkanie, a więc podkreślając jej dialogiczny charakter, chciałbym podążać dwoma ścieżkami, które pozwolą w sposób bardziej klarowny zrozumieć to, co dla wiary jest - by posłużyć się określeniem Bernharda Weltego - istotowe. Pierwszym ważnym momentem będzie określenie tego, co nazywamy wiarq jako wiara, czyli próba zrozumienia tego, co jest istota wiary. Drugim momentem jest pokazanie istotowego charakteru aktu wiary, w którym podejście dialogiczne odgrywa - jak sądzę - fundamentalną rolę.

2 Obecny tekst jest zmienioną, poprawioną i rozszerzoną wersją referatu wygłoszonego we Wrocławiu podczas Colloquia Tischneriana Wratislaviensia, 6 kwietnia 2011 roku, i nie był do tej pory publikowany. Tekst ten poświęcony jest zasadniczo myśli czeskiego filozofia i teologa, konfrontowanego z myślą Josepha Ratzingera i Józefa Tischnera. Dlatego też postanowiłem dość obszernie, jeśli tylko tego wymaga tekst, przytaczać wypowiedzi Tomasza z Pragi, jak określał go abp Józef Życiński. Prezentowany tekst nie jest w swym zamierzeniu całościowym i wyczerpującym omówieniem myśli czeskiego teologa, a tym bardziej myśli Josepha Ratzingera czy Józefa Tischnera. Jest jedynie pewną próbą, zaproszeniem do dyskusji nad zagadnieniem dialogiczności wiary. Por. też mój pierwszy tekst poruszający to zagadnienie: M. Manikowski, Wiara jako relacja odniesienia człowieka do Boga, [w:] Filozofia religii, red. J. Baniak, Poznań 2006, t. 2, s. 15-31. 
Jednak zanim do tych rozważań przejdę, chciałbym zatrzymać się na moment nad wskazaniem różnicy między religią a wiarą, gdyż w dzisiejszych czasach dość często spotkać można synonimiczne rozumienie obu tych terminów, co pojawia się bardzo często w kontekście rozważań o tzw. powrocie religii.

\section{Religia a wiara}

Próba pokazania różnic między religią a wiarą nie musi prowadzić do wyraźnego ich przeciwstawiania, ale jedynie do uwydatnienia tego, co je różni, choć niekoniecznie musi je dzielić. W sposób jakże sugestywny pisze o tym rozróżnieniu Tomáš Halík:

Systemy przekonań religijnych są „garderobą" wiary, odzwierciedlają gust i styl poszczególnych epok i kultur, poprzez które wiara przechodzi. Religia jest głębinową strukturą społeczeństwa i jego kultury; religia buduje i integruje ludzki świat - wiara przekracza mury. Religia jest środowiskiem domowym, w które człowiek rodząc się wchodzi; wiara natomiast jest sprawą wyboru, decyzji, dobrowolnej odpowiedzi na wezwanie - i udaniem się w drogę ${ }^{3}$.

Tomáš Halík zatem podkreśla, że religia (czy raczej jej kultyczny wyraz) jest pewną obudowa dla tego, co jest wiarą, egzystencjalną postawą człowieka wobec Boga, świata i człowieka; religia jest tym, co zostaje ukształtowane przez kulturę i społeczeństwo, w których wiara żyje swym życiem; wiara jest egzystencjalną postawą, postawą decyzji, wolnego wyboru, wyjściem w drogę czy - po prostu - przekraczaniem granic (o rozumieniu wiary jako drogi będę jeszcze pisał). Patrząc na wiarę w kontekście jej opozycji do religii, Tomáš Halík pisał w innym miejscu:

Wiara jest wolna odpowiedzia człowieka na Boże wezwanie. Religia jest sprawą tradycji, zbiorowości, komunikacji, autorytetu - wiara zakłada oso-

3 T. Halík, Co nie jest chwiejne, jest nietrwałe. Labiryntem świata $z$ wiarą i wątpliwościami, tłum. J. Zychowicz, Kraków 2004, s. 115. 
biste nawrócenie i przemianę, metanoia; ściśle mówiąc, „wiary” nie można odziedziczyć

Wiara zatem jest czymś innym niż religia, choć obie rzeczywistości są nierozerwalnie ze sobą powiązane. Podkreślając zarówno te różnice, jak i to, co je łączy, Tomáš Halík wyraźnie wskazuje na dialogiczny charakter wiary. Przytoczmy więc jego słowa, traktując je w tym miejscu jako bardzo poręczne wprowadzenie do głównego zagadnienia tego tekstu:

Wiara $\mathrm{w}$ takim ujęciu nie jest zbiorem metafizycznych przekonań, ale wyraża się w naszej relacji do całej rzeczywistości. Wierzącym jestem wtedy, gdy mam do świata nie manipulacyjny, „monologiczny” stosunek, ale stosunek dialogiczny, który (przynajmniej podświadomie, implicite) zakłada i zawiera w sobie relacje wobec horyzontu ,absolutnego Ty" .

Joseph Ratzinger próbując teologicznie rozjaśnić pojęcia wiary i religii, a czyni to w kontekście objaśniania stanowiska ekskluzywizmu teologicznego, prowadzi w swych rozważaniach do wskazania istoty chrześcijaństwa i jego stosunku do religii światowych. Pisze:

Wydaje mi się, że pierwszorzędnym postulatem pod adresem zróżnicowanej teologii religii jest precyzyjne wyjaśnienie pojęć „wiara” i „religia”, gdyż oba są mętne i najczęściej tyleż ze sobą mylone, co uogólniane. Dlatego mówi się o „wiarach” w liczbie mnogiej i ma się na myśli wszystkie religie, mimo że pojęcie „wiara” nie występuje we wszystkich religiach, a przynajmniej nie dla wszystkich jest konstytutywne, a jeśli występuje - jest różnie rozumiane. I odwrotnie - rozszerzenie pojęcia religii jako ogólnej nazwy stosunku człowieka do Transcendencji nastąpiło dopiero w drugiej połowie czasów nowożytnych ${ }^{6}$.

$4 \quad$ Tenże, Wzywany czy niewzywany Bóg się tutaj zjawi. Europejskie wykłady z filozofii i socjologii dziejów chrześcijaństwa, tłum. A. Babuchowski, Kraków 2006, s. 99.

Tamże, s. 107; podkreślenie moje - M. M.

6 J. Ratzinger, Wiara - prawda - tolerancja. Chrześcijaństwo a religie świata, tłum. R. Zajączkowski, Kielce 2005, s. 42. Refleksje te pojawiają się w kontekście polemiki z teologią Kar- 
To, co staje się tutaj najważniejsze, w kontekście przytoczonej myśli kardynała Ratzingera można wyrazić w słowach: wiara może przejawiać się w życiu człowieka jako religia (przywołać tutaj można Halíkową „garderobę wiary"), ale nie zawsze musi się ona do religii sprowadzać.

Konstatacja Josepha Ratzingera wydaje się w punkcie wyjścia dość oczywista - nie powinno się w sposób bezkrytyczny utożsamiać zakresów pojęć wiary i religii. To, że znaczą one coś innego, choć nie do końca sobie przeciwnego, pokazuje zdroworozsądkowe myślenie. Oczywiście, pozostają nadal ważne pytania, które dotyczą tak wiary, jak i religii, ich wzajemnego stosunku i tego, co dla nich teologicznie i filozoficznie istotne. Warto jednak zwrócić uwagę na to, co powiada kardynał Ratzinger pod koniec przytoczonego fragmentu. Mówi on bowiem - z jednej strony - o religii biorącej pod uwagę stosunek człowieka do Transcendencji, a z drugiej strony wyraźnie podkreśla, iż to wzbogacenie rozumienia religii jest dziełem czasów nowożytnych. Wydaje się, że to wskazanie podkreśla ten zasadniczy moment, kiedy pola zakresowe tego, co rozumiemy przez wiarę, i tego, co rozumiemy przez religię, zaczynają na siebie nachodzić, zaczynają się wzajemnie zazębiać. Czas więc zastanowić się nad problemem zasadniczym: Czym jest - $w$ istocie swej - wiara?

\section{Wiara nie jest wiedzą}

Podejście do tak postawionego pytania może być dwojakie, można bowiem próbować określić wiarę na drodze negatywnej, a więc scharakteryzować ją poprzez pryzmat tego, czym ona nie jest, ale można też pokusić się o próbę charakterystyki pozytywnej, skłaniającej nas do poszukiwania tych cech, które można byłoby uznać za definicyjne (choć nie zawsze musimy mieć na myśli definicję w sensie ścisłym). Nie jest moim zadaniem w tak krótkim tekście całościowe potraktowanie wyjściowego zagadnienia, można jedynie poprzestać na pewnych wskazówkach.

la Bartha. Ponieważ w tekście odwołuję się głównie do tekstów powstałych przed 2005 rokiem, konsekwentnie używał będę nazwiska Ratzinger, niekiedy tylko, gdy zajdzie taka potrzeba, użyję imienia Benedykt XVI. 
Negatywne charakteryzowanie wiary przybiera zawsze rozważanie jej w relacji do wiedzy. Funkcjonowanie człowieka w świecie nacechowane jest pewną dwubiegunowością - z jednej strony są obszary, w których dominuje wiedza, a wraz z nią pewność, a z drugiej strony, $\mathrm{w}$ wielu życiowych momentach wiedza zastępowana jest przez wiarę, dodajmy: wiarę życia codziennego. Joseph Ratzinger opisuje to tak:

Żyjemy otoczeni przez rzeczy, których do końca nie znamy, ale którym ufamy, opierając się na doświadczeniach - w większości pozytywnych. „Wierzymy”, że te są godne zaufania, i dzięki tej „wierze» możemy uczestniczyć w wiedzy innych ludzi. (...) Z jednej strony, w naszym życiu tego rodzaju wiara jest niezbędna. Bez niej nic nie mogłoby funkcjonować, każdy musiałby zaczynać od początku. Ludzkie życie staje się niemożliwe, jeśli nie może zaufać ich doświadczeniu, ich wiedzy, temu, co od nich słyszy. Jest to jeden z aspektów tej wiary - aspekt pozytywny. $\mathrm{Z}$ drugiej - wiara ta jest oczywiście wyrazem niewiedzy i w tym sensie jest podstawą wtórną: byłoby lepiej gdybyśmy wiedzieli .

\section{Tomáš Halík dodaje:}

Przypomnijmy, że jeden z klasyków współczesnego krytycznego racjonalizmu, Karl Popper, otwarcie przyznaje, że jego racjonalizm opiera się na wierze jako ostatniej instancji, którą on sam nazywa wyraźnie swoją „irracjonalną wiarą w rozum". Wielu ludzi dalekich od jakiejkolwiek religii opiera nie tylko szereg swoich przekonań, ale także zasadniczych decyzji i postaw życiowych na wynikającej z ufności wierze, a nie na czymś, co empirycznie sprawdzili czy też logicznie udowodnili ${ }^{8}$.

Zaprezentowane fragmenty tekstów Josepha Ratzingera i Tomáša Halíka odsyłają nas do dwóch aspektów. Pierwszym jest wymiar praktyczny, chyba najmocniej podkreślony przez czeskiego teologa dzięki odwołaniu się do aspektu naszych „życiowych decyzji”. Bez zaufania, bez zaufania do

$7 \quad$ Tenże, Patrzeć na Chrystusa, tłum. J. Merecki, Kraków, s. 10.

$8 \quad$ T. Halík, Co nie jest chwiejne..., dz. cyt., s. 165. 
wiedzy innych ludzi, zaufania, które jest przecież naszą wiarą codziennego życia, funkcjonowanie człowieka w świecie byłoby bardzo utrudnione, by nie powiedzieć, całkowicie niemożliwe. Każdego bowiem dnia, nie opierając się na zaufaniu do innych, musielibyśmy sami, w oparciu o swą własną, często bardzo szczątkową wiedzę, nasze własne empiryczne doświadczenia czy przemyślenia, podejmować decyzje. A tak, polegając na wiedzy innych, wierząc w ich doświadczenie i ich wiedzę, ułatwiamy sobie codzienne bycie w świecie. Takie nasze-bycie-w-świecie oparte jest więc na zaufaniu, na wzajemnym zaufaniu, na wspólnocie zaufania i wspólnocie uczestniczenia w rozumieniu tego świata, a z drugiej strony na prostej akceptacji tego, że jest to coś niedostatecznego, tymczasowego, wstępnego, że jest to jedynie pierwszy krok w stronę wiedzy, jeśli tylko wysiłek zdobywania wiedzy zostanie przez nas podjęty. Struktura tak pojmowanej wiedzy jest - jak wskazuje kardynał Joseph Ratzinger - trojaka:

Możemy teraz wymienić elementy, które składają się na tę wiarę (elementy, z których składa się jej „struktura”). Istnieją trzy takie elementy. Po pierwsze, tego rodzaju wiara zawsze odnosi się do kogoś, kto „wie”: zakłada rzeczywistą wiedzę, którą posiadają osoby odpowiednio przygotowane i godne wiary. Drugim elementem jest zaufanie wielu ludzi, którzy używając codziennie różnych rzeczy, opierają się na rzetelności wiedzy leżącej u ich podstaw. Trzecim elementem jest pewnego rodzaju weryfikacja wiedzy w codziennym doświadczeniu?

Tak przedstawiona wiara, zwana przez bawarskiego teologa wiarą życia codziennego, pokazuje to, co wydaje się zasadnicze: choć wiara życia codziennego jest powiązana $z$ wiedzą (szczególnie wiedzą innych ludzi), sama, jako wiara, wiedzą nie jest. Z jednej strony, co jest poniekąd konsekwencją powyższego, wiary właściwie nie można się nauczyć, tak jak każdej innej wiedzy. Joseph Ratzinger podpowiada:

Wiara w Boga nie jest formą wiedzy, tak jak chemia czy matematyka, których mogę się nauczyć, lecz pozostaje wiarą. To znaczy: wiara ma racjonalną struktu- 
rę (...). Nie jest jakąś ciemną rzeczą, którą musiałbym po prostu przyjąć. Wiara daje mi wgląd. I przemawia za nią dostatecznie wiele argumentów, w które mogę uzyskać wgląd. Ale wiara nigdy nie stanie się czystą wiedzą. Wiara zwraca się do całej egzystencji, do woli, do miłości, do samowyrzeczenia, dlatego zawsze wymaga również przekroczenia wiedzy, dowodów. A ponieważ tak jest, zawsze mogę też żyć z dala od wiedzy i szukać argumentów, które ją obalają ${ }^{10}$.

\section{A dalej, niejako kończąc wcześniej rozpoczętą myśl, bawarski teolog dodaje:}

Wiara nie daje się zrozumieć tak jak dowolna formuła matematyczna, nigdy nie staje się dla mnie całkowicie przejrzysta - wiara wnika w coraz głębsze warstwy, w nieskończoność Boga, w misterium miłości. W tej sferze czysto myślowe rozumienie napotyka granicę. Jako ograniczona istota nie wszystko mogę zrozumieć i w pełni zbadać rozumowo ${ }^{11}$.

Gdybyśmy chcieli traktować wiarę jako to, czego można się nauczyć, łatwo sprowadzilibyśmy ją do ideologii. Tomáš Halík podkreśla: „Nie jest to [wiara - M. M] ideologia, która mogłaby być narzędziem zdobycia władzy, nie jest to niezawodna recepta na zwycięstwo w walce między konkurującymi interesami"12, i nawiązując do myśli Josepha Ratzingera, dodaje:

Wiara, tak jak ją w duchu biblijnych proroków oraz wielkich mistyków i teologów chrześcijaństwa (ale także judaizmu i islamu) rozumiem, nie jest i nie może być „teizmem” ani żadnym innym „izmem”, ponieważ wtedy przerodziłaby się w swoje przeciwieństwo, w ideologię i idolatrię, pogańskie bałwochwalstwo. Walka przeciwko bałwochwalstwu jest walką przeciwko zamianie symbolu na przedmiot, który wskazuje ${ }^{13}$.

10 Bóg i świat. Wiara i życie $w$ dzisiejszych czasach. Z kardynałem Josephem Ratzingerem rozmawia Peter Seewald, tłum. G. Sowinski, Kraków 2001, s. 28.

11 Tamże, s. 42.

12 T. Halík, Dotknij ran. Duchowość nieobojętności, tłum. A. Babuchowski, Kraków 2010, s. 167.

13 Tenże, Drzewo ma jeszcze nadzieję. Kryzys jako szansa, tłum. A. Babuchowski, Kraków 2010, s. 161. 
Wiara zatem, patrząc z perspektywy negatywnej, apofatycznej, nie jest wiedzą, a przynajmniej nie jest wiedzą w rozumieniu nauk ścisłych, choć zapewne nie jest nią również w sensie nauk humanistycznych i społecznych. Dlaczego? Bo, jak podkreślają Joseph Ratzinger oraz Tomáš Halík (i zapewne nie tylko oni), nie można się jej nauczyć, jak w przypadku innych nauk, nie można również stosować w niej i nie stosuje się takich samych metod argumentowania, jak właśnie w naukach. Nie jest też wiedzą, gdyż nie do końca opiera się na rozumowaniu, choć nie neguje się jej racjonalnej struktury, lecz na tym, co kardynał Ratzinger nazywa wgladem. Poprzez takie podejście do tego zagadnienia pokazane zostaje coś, co jest - jak sądze - fundamentem w rozumieniu wiary: nie odwołuje się ona do rozumu, intuicji czy uczuć, ale do całego człowieka. Wydaje się, że ten aspekt, nazwijmy go tutaj egzystencjalnym, choć nie w znaczeniu specyficznego prądu filozoficznego, jest zazwyczaj pomijany lub całkowicie zapominany przy analizie wiary. Nie jest ona, podkreśle to raz jeszcze, domeną jakiejś władzy człowieka, ale jest specyficzna dla całego człowieka. Spróbujmy zatem popatrzeć na wiarę z perspektywy pozytywnej.

\section{Wiara jako zawierzenie}

Rozważając problem wiary, szczególnie w perspektywie teologii Pawłowej czy filozofii Kierkegaarda, niemal automatycznie przywołujemy postać Abrahama, zwanego przecież ojcem wiary. Jednak polski filozof spotkania, Józef Tischner, pokazuje, że przy podejmowaniu zagadnienia wiary należy wziąć pod uwagę nie jedną, ale dwie biblijne postacie: Adama i Abrahama (Tomáš Halík doda tutaj, o czym poniżej, jeszcze jedną postać, tym razem z greckiej mitologii ${ }^{14}$.

Zrozumieć fenomen wiary, to zrozumieć postawę Adama i Abrahama. Bo, jak podpowiada Józef Tischner, Abraham jest tym, który „naprawia błąd Adama”. Na czym więc ów błąd Adama polegał? W jednym ze starosądeckich kazań krakowskiego filozofa czytamy:

14 Podobnie czyni również Józef Tischner, wspominając Abrahama i Odyseusza. Por. J. Tischner, Filozofia dramatu. Wprowadzenie, Kraków 1999, s. 28-29, 41. 
Adam w odpowiedzi na wołanie Boga skrył się, nie chciał się Bogu pokazać. Nie uwierzył, nie zawierzył. Abraham jakby naprawia błąd Adama. Na wołanie Boga, na Jego wybór, odpowiada wyborem ${ }^{15}$.

Kiedy Bóg woła Adama, kiedy zadaje mu jedno z najbardziej fundamentalnych pytań w historii człowieka: „Adamie, gdzie jesteś?”, Adam ucieka i chowa się w zaroślach. Widząc jednak swą klęskę, klęskę podwójną - złamanie Bożego zakazu i ucieczkę przed Bogiem - decyduje się wreszcie na wołanie Boga odpowiedzieć, ale jest to odpowiedź raczej wymijająca niż sięgająca $\mathrm{w}$ głąb, czyli do istoty tego, co się stało. Adam, choć decyduje się odpowiedzieć na wołanie Boga, mimo wszystko znów ucieka. Abraham inaczej. Kiedy Bóg go woła, Abraham staje w gotowości i odpowiada: „Oto jestem!”, czyniąc ze swej odpowiedzi wzorzec reakcji każdego człowieka, człowieka wiary. I w połączeniu obu tych opowieści, czy raczej ich teologicznych interpretacji, widać, jak powiedziałby Józef Tischner, istotę wiary, widać dwie zasadnicze cechy wiary.

Pierwszą z nich jest wybór. Bóg wybiera człowieka i kieruje do niego swe słowo. Widać to nie tylko w przypadku Abrahama, ale również, a może szczególnie, w przypadku innego biblijnego bohatera, Mojżesza, wybranego przez Boga na tego, który wprowadzi Izraela do Ziemi Obiecanej, czy w przypadku apostołów wybranych przez Jezusa Chrystusa do działalności misyjnej czy choćby do uczestniczenia w Jego Tajemnicy (Góra Przemienienia). Ale ten wybór, będąc jedynie początkiem, musi za sobą pociągać to, co staje się drugą cechą istotową wiary - mianowicie odpowiedź. „Na wybór odpowiada wyborem" - konstatuje w odniesieniu do Abrahama Józef Tischner ${ }^{16}$. Wiara zaczyna się od wybrania, zaczyna się od pytania, zaczyna się od zawołania, od zagadnięcia, ale nie może się na tym pytaniu czy zawołaniu zakończyć, musi bowiem pociągać za sobą odpowiedź, która jest dalszym ciągiem wybrania.

15 Tenże, Wiara ze stuchania. Kazania starosądeckie 1980-1992, Kraków 2009, s. 132.

16 Tamże, s. 132. 
Wiara to wierność. A kiedy mowa o wierności, znowu widzimy przed oczyma postać wielkiego ojca wiary: postać Abrahama. Wierny. Wierny to znaczy: wybierający. Wybrany - wybierający ${ }^{17}$.

A to pokazuje, że wiara w rozumieniu Józefa Tischnera jest dialektyką wybranego i Wybierającego, jest, bo musi być - sprzężeniem tego, który został wybrany, z Tym, który go wybrał.

Komentując te słowa warto odwołać się do innego „zestawienia” ludzi dokonujących wyboru, jakie znajdujemy w pracach Tomáša Halíka. Czeski teolog, idąc za francuskim filozofem dialogu Emmanuelem Lévinasem, zestawia ze sobą Abrahama i Odyseusza. Pisze:

Wiara oznacza wyjście skądś, „wyruszenie w drogę”. „Abram uwierzył Panu i udał się w drogę, chociaż nie wiedział, dokąd idzie”. Emmanuel Lévinas wymienia dwa różne paradygmaty drogi życiowej, leżące u podstaw zachodniej kultury: historię Odyseusza, który po swoich przygodach powraca do rodzinnej Itaki, i Abrahama, który wyrusza w drogę i wie, że już nigdy nie powróci. Podobnie Mojżesz i jego lud ${ }^{18}$.

Zestawienie Abrahama i Odyseusza pomaga nam zrozumieć to, co dla wiary jest, choćby zdaniem Halíka, najbardziej istotne. Odyseusz wyruszając w drogę, wraca do domu, wraca do tego, co jest mu znane; Abraham wyruszając w drogę, wychodzi z domu, wychodzi z tego, co jest mu znane, i - ruszając w drogę - idzie ku nieznanemu, ale obiecanemu przez Boga (stąd porównanie Abrahama z Mojżeszem). Wiara zawsze jest dla nas wyjściem z pewności, z tego, co nam dobrze znanym, i oswojonym, i pójściem na spotkanie z Tajemnicą. I chociaż zawsze jest to podróż do celu, to nigdy, od samego początku wędrowania, tego celu nie widzimy i nie znamy, choć jest w naszej perspektywie jako nadzieja. Czas jednak dostrzec, że tak pojmowana wiara prowadzi nas do kolejnego etapu na drodze jej rozjaśniania.

17 Tamże, s. 131.

18 T. Halík, Co nie jest chwiejne..., dz. cyt., s. 114. 
Jednocześnie tak rozumiana wiara jest pewnym dążeniem. Można je rozumieć na dwa sposoby: metodycznie i egzystencjalnie. To skierowanie naszego myślenia na trop metody widać wyraźnie w nieustannym dążeniu kardynała Josepha Ratzingera do podkreślania racjonalnego charakteru (czy też struktury) wiary. Nie ma tutaj możliwości całościowego podjęcia tego tematu, bardzo ważnego dla zrozumienia i samej wiary, i Ratzingerowskiego doń podejścia. Warto jednak w tym miejscu przytoczyć pewien znamienny fragment, podkreślający rozumienie wiary jako dążenia. Czytamy:

Wiara w samym swoim wnętrzu jest, jak mówią Ojcowie, querens intellectum, szukająca zrozumienia. Rozumienie, a więc racjonalne zajęcie się danym wcześniej słowem, konstytutywnie należy do wiary. W sposób konieczny prowadzi do teologii. Odróżnia to wiarę chrześcijańską, także i w perspektywie historii religii, od wszystkich pozostałych systemów religijnych. Teologia jest fenomenem specyficznie chrześcijańskim, wynikającym ze struktury tej wiary ${ }^{19}$.

Wiara właśnie poprzez ten aspekt poszukiwania swego zrozumienia staje się dążeniem, bowiem człowiek wierzący, właśnie jako wierzący, siłą rzeczy chce swą wiarę zrozumieć. Może to jednak być też dążenie bardziej egzystencjalne, czyli dotyczące całego człowieka. Józef Tischner pisze:

Czym jest wiara? Jest dążeniem. Można powiedzieć tak, że jesteśmy jakby w tej samej rzece, tylko jedni są dopiero na początku, gdzieś u źródła, inni są w środku, a inni znajdują się już tam, dokąd wszystkie rzeki wpływają - w niebieskim morzu, w tym morzu obok Jezusa Chrystusa. Na tym polega duch wiary. Na tym polega życie wiary, na tym polega miłość ${ }^{20}$.

Wiara to droga, droga, którą pokonujemy wszyscy, droga prowadząca w tym samym kierunku, droga angażująca całego człowieka, droga

19 J. Ratzinger, Prawda w teologii, tłum. M. Mijalska, Kraków 2001, s. 120.

20 J. Tischner, Wiara ze stuchania, dz. cyt., s. 171. 
zawsze polegająca na byciu wybranym i zaakceptowaniu tego wybrania. To jednak pokazuje, że wiara ma zawsze charakter relacyjny. Wiara to wędrowanie. Tomáš Halík komentuje to tak: „Wiara jest «kontynuacją», przypomina na tym świecie nigdy niekończącą się drogę" ${ }^{21}$. Dlaczego jest to „niekończąca się droga”? Bo jest to droga, mówiąc słowami Józefa Tischnera, do nieba, czyli droga na tym świecie się niekończąca. Dlatego, zdaniem czeskiego teologa, Abraham jest dobrym przykładem nie człowieka religii, tylko człowieka wiary. Czytamy:

Abraham nie za bardzo może być symbolem religii jako zbioru rytuałów, doktryn, nakazów i zakazów, może być jednak symbolem dynamicznego charakteru wiary. Abraham jest symbolem człowieka, do którego Bóg przemówił i któremu wskazał drogę. Wiara Abrahama oznacza wyjście, wyruszenie w drogę $e^{22}$.

Ponieważ droga ta jest niekończącym się na tym świecie wędrowaniem, podróżowaniem w nieznane, potrzebna jest, zdaniem Tomáša Halíka, cnota cierpliwości, gdyż bez niej nie będziemy w stanie na tej wybranej przez nas drodze wytrwać ${ }^{23}$.

\section{Wiara i wątpliwości}

Rozumiejąc wiarę jako wędrowanie, więcej - jako podróżowanie ku nieznanemu, nie można pominąć jakże ważkiej kwestii wątpliwości, jakie - zdaniem Tomáša Halíka - w naturalny sposób pojawiają się w przestrzeni naszej wiary. Kiedy wcześniej, zestawiając wiarę z nauką, powiedziałem, że nauka jest tą przestrzenią, w której dominuje pewność, miałem na myśli pewien fundamentalny dla rozumienia fenomenu wiary fakt, że jest ona zawsze poddawana wątpliwościom. Nie ma wiary bez wątpliwości. Dlaczego? Dlatego, że tylko w przestrzeni wątpliwości, dodajmy:

${ }_{21}$ T. Halík, Cierpliwość wobec Boga. Spotkanie wiary z niewiara, tłum. A. Babuchowski, Kraków 2009, s. 23.

22 Tenże, Wzywany czy niewzywany..., dz. cyt., s. 258.

23 Por. tenże, Cierpliwość wobec Boga, dz. cyt., s. 112, 192. 
ludzkich wątpliwości, wiara jest powiązana z wolnością. Czeski teolog pisze: „Bóg pozostawił przestrzeń dla wątpliwości, żeby wiara nie utraciła godności wolnego aktu i odważnego wejścia w królestwo Tajemnicy”24. To pozostawanie $\mathrm{w}$ sferze wątpliwości oznacza nieustanne stawanie $\mathrm{w}$ obliczu pytań, pytań ważnych, niekiedy naruszających gmach zbudowanej przez nas pewności, jednak nie mających mocy zburzyć fundamentu naszej wiary, jakim jest zaufanie do Boga, który nas wybrał i któremu odpowiedzieliśmy w wolnym akcie decyzji. Tomáš Halík pisze:

Być wierzącym nie oznacza odrzucić na zawsze brzemię palących pytań. Czasami znaczy to wziąć na siebie krzyż wątpliwości i - idąc z nim - wiernie naśladować Chrystusa. Siła wiary nie polega na „niezachwianym” przekonaniu, ale na tym, czy potrafimy udźwignąć również wahania, niejasności, znosić ciężar tajemnicy - a przy tym zachować wierność i nadzieję. (...) Wiara tu na ziemi nie jest „pewnością”, lecz otwartością na Niepojętego w pytaniu, szukaniu, niekiedy w krzyku, łzach i proteście, ale także w nieustannej prośbie o ufność i wytrwałość, w odwadze niekontentowania się powierzchownymi, zbyt łatwymi odpowiedziami i wyjaśnieniami ${ }^{25}$.

Czeski teolog zwraca uwagę na kilka niezwykle ważnych w pojmowaniu wiary aspektów. Pierwszym jest ten, w którym podkreślona zostaje konieczność „niezadowalania się" łatwymi rozwiązaniami, które zawsze prowadzą do zaskorupienia się w czymś, co wydaje się nam pewnością, a co nią nie jest, a jest jedynie uciekaniem przed pojawiającymi się trudnościami. Niekiedy w życiu codziennym łatwiej jest uciec właśnie w takie schowanie się, niż z otwartą przyłbicą zmagać się z własnymi (właśnie: własnymi!) wątpliwościami. Kolejnym aspektem jest otwartość wiary, otwartość na pytania, czasami trudne i fundamentalne, ale również i otwartość na nadzieję znalezienia odpowiedzi, a więc i otwartość na Tajemnicę, ku której w wierze się zbliżamy. Wiara jest

24 Tenże, Drzewo ma jeszcze nadzieję, dz. cyt., s. 16. Na wolnościowy aspekt wiary powołuje się cytowany już wcześniej, Katechizm Kościoła Katolickiego (160).

${ }_{25}$ Tenże, Dotknij ran, dz. cyt., s. 22 i 24. Por. tenże, Wzywany czy niewzywany, dz. cyt., s. 23, 27. 
zmaganiem się, wiara jest, by sparafrazować słowa z Księgi Hioba, bojowaniem, a w to trzeba niejako wpisywać wszelakie potknięcia czy poważne zatrzymywania, by mieć czas na zastanowienie się, bo tylko powolne zmierzanie do celu ma szansę być zrealizowane.

\section{Wiara jako odpowiedź}

Kiedy w naszych rozważaniach pojawiają się biblijne postacie Adama i Abrahama, a w sposób szczególny Mojżesza stojącego u stóp Bożej góry Horeb, ale również i mitycznego Odyseusza, niemal natychmiast pojawia się zagadnienie rozumienia wiary jako rozmowy, jako spotkania, jako dialogu. Warto w tym miejscu zobaczyć te elementy, które do wiary doprowadzają.

Przede wszystkim jest to, jak już było to wielokrotnie podkreślane, odpowiedź na usłyszane słowo, na zawezwanie, bowiem to słowo wprowadza ową relacyjność w wiarę. Bernhard Welte, niemiecki teolog i filozof, pisze:

Słowo dokonuje się jako relacja. Ta relacja wypływa zawsze od mówiącego. Nie można jej wyprowadzić w kierunku przeciwnym, tzn. do niego. Ta relacja zawsze wypływa od niego i kieruje się poza niego do zagadniętego, przez którego chce być usłyszana, zrozumiana, a w pewnych przypadkach nawet przyjęta ${ }^{26}$.

Mamy zatem, jak odczytujemy to z tekstu Weltego, trzy sfery: mówiącego, zagadniętego i relację, jaka została między nimi nawiązana ${ }^{27}$. Ktoś kieruje do człowieka słowo, ono czyni z adresata tego, do którego słowo to zostało skierowane, czyli - używając terminologii Weltego - zagadniętego, a on, czując się zagadnięty i odpowiedzialny za wysłane w jego kie-

26 B. Welte, Czym jest wiara? Rozważania o filozofii religii, tłum. W. Patyna, Warszawa 2000, s. 11. Por. tenże, Filozofia religii, tłum. G. Sowinski, Kraków 1996; J. Tischner, Filozofia dramatu, dz. cyt., s. 101-104.

27 Koncepcja człowieka zawezwanego pochodzi źródłowo od Ferdinanda Ebnera. Por. F. Ebner, Słowo i realności duchowe. Fragmenty pneumatologiczne, tłum. K. Skorulski, Warszawa 2006, s. 12-19. 
runku słowo, odpowiada na nie, i tym samym zostaje nawiązana relacja. Ważne jest to, że nie ma relacji do momentu pojawienia się odpowiedzi. To niejako odpowiedź na zagadnięcie funduje relację. Kiedy Bóg kieruje do nas swe słowo, a my, jak Abraham czy Mojżesz, odpowiadamy na nie „Oto jestem!”, wtedy będąc zagadnięci przez Boga, nawiązujemy z Nim poprzez naszą odpowiedź relację, którą nazwać można wiarą ${ }^{28}$.

Jednak to spotkanie Boga i człowieka, podobnie jak spotkanie człowieka i człowieka, dzieje się w pewnej przestrzeni. Józef Tischner nazywa tę przestrzeń miejscem.

Miejsce powstaje tam - pisze - gdzie człowiek kogoś spotyka, gdzie spotyka Boga. Człowiek, który nikogo nie spotyka, który przechodzi przez świat, zamykając się na ludzi, na ich potrzeby, zamykając uszy na ich głos, człowiek, który nigdy nie spotyka Boga - nie ma na ziemi miejsca ${ }^{29}$.

Dostrzegamy tutaj istotny moment filozoficznego myślenia krakowskiego filozofa. Miejsce jest w jakiś sposób wtórne w stosunku do relacji człowiek - człowiek czy człowiek - Bóg. To dopiero ta relacja, relacja spotkania, konstytuuje miejsce, konstytuuje przestrzeń spotkania. Bez spotkania nie byłoby miejsca. Dlatego najbardziej fundamentalnym miejscem spotkania jest świątynia, miejsce święte:

Świątynia jest miejscem. Miejsce powstaje tam, gdzie człowiek spotyka człowieka. Dom jest miejscem, bo jest miejscem spotkania rodziny. Świątynia jest miejscem, bo jest miejscem spotkania ${ }^{30}$.

Mamy tutaj do czynienia $\mathrm{z}$ dwoma zazębiającymi się sferami: $\mathrm{z}$ jednej strony, jest relacja słowa, jaka nawiązuje się między mówiącym a zagadniętym, a z drugiej strony, jest to przestrzeń, która zostaje w wyniku tego spotkania stworzona. Mamy tutaj swoistą dialektykę człowieka

28 Por. T. Halík, Wzywany czy niewzywany, dz. cyt., s. 107.

29 J. Tischner, Wiara ze stuchania, dz. cyt., s. 133.

30 Tamże, s. 17. 
i przestrzeni. Odnosząc się do bardzo podobnego problemu, Joseph Ratzinger napisze:

Znamienne dla człowieka - patrząc od góry - jest to, że Bóg do niego przemówił, a więc że jest uczestnikiem dialogu z Bogiem, że jest istotą powołaną przez Boga. Gdy patrzymy od dołu, znaczy to, że człowiek jest istotą, która może pomyśleć o Bogu, istotą otwartą na transcendencję. Nie chodzi tu o to, czy naprawdę człowiek o Bogu myśli, ku Niemu się otwiera, tylko o to, że zasadniczo jest istotą, która do tego jest zdolna, nawet jeśli faktycznie z jakichkolwiek powodów nie może tej zdolności urzeczywistnićc ${ }^{31}$.

Joseph Ratzinger zwraca uwagę, jak sądzę, na dwa momenty. Po pierwsze, na samą relację między Bogiem a człowiekiem, po drugie, na jej aktualny bądź potencjalny charakter. Człowiek jest zdolny do nawiązania relacji z Bogiem, czyli do odpowiedzi na wypowiedziane słowo, ale nie zawsze musi się to aktualizować. Przyczyny nierealizowania się tej możliwości mogą być różnorakie, jak choćby i to, że w zgiełku dzisiejszego świata, w zanurzeniu się w otaczającej nas rzeczywistości możemy po prostu głosu Boga nie usłyszeć.

Co zatem można o tym relacyjnym charakterze wiary powiedzieć? Pierwszym momentem, jaki zostaje tutaj podkreślony, jest indywidualność aktu wiary, indywidualność odpowiedzi na skierowane słowo. Jeśli ktoś kieruje swe słowo, to kieruje je do mnie, a nie do kogoś innego. Jeśli kieruje swe słowo do mnie, to jedynie ode mnie oczekuje odpowiedzi, a nie od kogoś innego. Nikt inny poza mną na zadane mi pytanie nie może odpowiedzieć, bo nikt inny poza mną nie jest do tej odpowiedzi wezwany. Kiedy Bóg wołał Adama, to kierował swe słowo tylko do niego, kiedy Bóg wołał Abrahama, to kierował swe słowo tylko do niego, kiedy Bóg wołał Mojżesza, kierował swe słowo tylko do niego. Kiedy Bóg nas wzywa, chce naszej odpowiedzi, chce - jak podpowiadał nam wcześniej Józef Tischner - naszego wyboru. Kiedy pada pytanie: „Czy wierzysz...”, odpowiedź może być tylko jedna: „Wierzę, gdy zostaje 
podkreślone moje $\mathrm{Ja}$ - „Ja wierzę". Zaznaczając ową indywidualność czy, mówiąc teologicznie, osobowość aktu wiary, Joseph Ratzinger pisze:

Akt wiary jest wyjątkowo osobistym aktem, który jest zakotwiczony w najbardziej wewnętrznej głębi ludzkiego „ja”. Ale właśnie będąc aż do tego stopnia osobistym, jest on jednocześnie aktem komunikowania. Własne „ja” w swojej głębokiej naturze jest zawsze związane $\mathrm{z}$ „ty" i odwrotnie: autentyczna relacja, która staje się „komunikowaniem”, może zrodzić się tylko w głębi osoby ${ }^{32}$.

To relacyjne rozumienie aktu wiary odsłania nam nie tylko indywidualny, ale przede wszystkim osobowy charakter owej relacji oraz - co $\mathrm{z}$ tego wynika - dialektykę ja i ty. Co znaczy więc bycie osobą?

\section{Rozumienie „osoby”}

Zrozumienie tego ważnego teologicznie i filozoficznie terminu jest dla nas fundamentem zrozumienia wiary jako relacji. Jednak do tego zrozumienia przybliży nas nie zachodnie, łacińskie, wywodzące się od Augustyna i Boecjusza, rozumienie tego terminu, ale greckie, wywodzące się od Ojców Kapadockich, a dziś przypominane przez prawosławnego teologa Ioannesa Zizioulasa ${ }^{33}$.

Studiując tradycję patrystyczną, można odkryć, że rozumienie osoby nie koncentruje się na takich pojęciach, jak racjonalność czy wolność (jak chciał na przykład Boecjusz), lecz na takich terminach, jak relacyjność i relacja, bowiem tylko model komunijny potrafi ukazać to, co dla człowieka jest najważniejsze, a mianowicie jego bycie stworzonym na obraz Boga. Ioannes Zizioulas zaznacza, iż bycie osobq ma charakter wyraźnie ekstatyczny, a nie jedynie statyczny. Czym w tym wypadku jest ekstaza? Ekstazę grecki teolog rozumie jako przekraczanie siebie, to znaczy

32 Tenże, Europa Benedykta w kryzysie kultur, tłum. W. Dzierża, Częstochowa 2005, s. 137.

33 Prawosławny teolog Ioannis Zizioulas odwołuje się w swej myśli do patrystycznych źródeł rozumienia greckiego terminu hypostasis. Trzeba jednak wspomnieć, iż na gruncie zachodnim rozumienie człowieka jako osoby poprzez odwołanie się do greckiego termin hypostasis pojawia się u Emmanuela Lévinasa. Por. E. Lévinas, Istniejący i istnienie, tłum. J. Margański, Kraków 2006, s. 103-138. 
jako umiejętność wychodzenia poza więzy swego własnego ja. Pozwala to więc zdefiniować bycie osobq jako - bycie $w$ relacji. Być osobą, to być czymś więcej niż jedynie bytem jednostkowym. Do opisu tego specyficznego bytu, specyficznie ludzkiego bytu, Ioannes Zizioulas adaptuje grecki termin - hipostaza (tym samym łączy antropologię z teologią trynitarną, w której pojęcie hipostazy odgrywa kluczową rolę). Osoba jest więc bytem ekstatycznym, czyli wychodzącym poza siebie i relacyjnie skierowującym się ku innym osobom, będąc jednocześnie bytem hipostatycznym, czyli nosicielem natury. Osoba zatem jest hipostaza, czyli jednostkowym, niepowtarzalnym, unikatowym, specyficznym, wyjątkowym i niepodzielnym bytem, ale jednocześnie jest ekstaza, czyli wychodzeniem poza te specyficznie ludzkie cechy. Greckie rozumienie osoby pokazuje więc to, co u łacinników nigdy się nie pojawiało - osoba "tworzy się" niejako na przecięciu bycia-w-sobie i bycia-dla-innych. A to podkreśla dynamiczny charakter osoby. ${ }^{34}$ Będąc niejako współczesnym głosem patrystycznych źródeł, Tomáš Halík podkreśli: „Człowiek jest człowiekiem w takiej mierze, w jakiej jest człowiekiem $\mathrm{z}$ innymi i dla innych"35. Te uwagi dwóch współczesnych teologów, greckiego oraz czeskiego, współbrzmią z przytaczanymi powyżej analizami Józefa Tischnera i Josepha Ratzingera.

Poprzez bycie hipostazą człowiek staje się - jak chcieli później myśliciele średniowiecza - sposobem istnienia natury. Człowiek nie istnieje inaczej jak tylko jako byt osobowy, osoba, w której istnieje natura ludzka. Bowiem sama $\mathrm{z}$ siebie natura istnieć nie może, musi więc zatem posiadać swój ontologiczny nośnik, a jest nim właśnie osoba ludzka. Tylko osoba jako specyficzny ontologicznie byt może bowiem ukonkretniać naturę $\mathrm{w}$ ten jedyny i niepowtarzalny sposób. Jednak - z metafizycznego punktu widzenia - człowiek, jak uczy tradycja filozoficzna, jest bytem. Odsyła to nas do także ważnej filozoficznie kwestii wzajemnej relacji między bytem a osobą. W tym aspekcie nawiązać trzeba - jak to zawsze ujmuje Ioannes Zizioulas - do filozoficznej rewolucji w greckim myśleniu, jaka

34 Por. J. D. Zizioulas, Human Capacity and Human Incapacity: A Theological Exploration of Personhood, „Scottish Journal of Theology”, vol. 28, no. 5, 1975, s. 407-408.

35 T. Halík, Dotknij ran, dz. cyt., s. 193. 
dokonała się za czasów Ojców Kapadockich, szczególnie w pracach metafizycznych i antropologicznych Grzegorza z Nyssy. Ks. Roman Małecki, pisząc o teologii Ioannesa Zizioulasa, komentuje to tak:

Owa relacyjność i otwartość na innego nie są czymś „dodanym” do istoty człowieka. Nie są tylko przypadłością upiększającą „indywidualną substancję natury racjonalnej". One go po prostu konstytuują. Zizioulas wyraża to dosadnie, mówiąc, iż poza wspólnotą istnieje tylko pustka, chaos i „tragizm nieurzeczywistnionej egzystencji”36.

Ekstatyczny charakter ludzkiej osoby, bycie w relacji do innych, bycie bytem komunijnym jest istotą bycia osobą, jest - by odwołać się raz jeszcze do słów Tomáša Halíka - istotą bycia człowiekiem. Osoby nie da się zrozumieć inaczej, jak tylko poprzez pryzmat owych dwóch cech charakterystycznych: bycia hipostazą i bycia ekstazą. Człowiek jest przede wszystkim bytem dla drugiego, czyli jest osobą, nie przestając jednocześnie być bytem, czyli hipostazą ${ }^{37}$.

Bycie osobą pozwala dostrzec osobę i w drugim człowieku, a może przede wszystkim w drugim człowieku. Sytuację tę Józef Tischner komentuje tak: „Nie ma i nie może być Ja bez Ty i Ty bez Ja”, i później dodaje:

W pewnym sensie jesteśmy monadami bez okien. Nie wiem, co się dzieje w tobie, ani Ty nie wiesz, co się dzieje we mnie. Niemniej wiem, że Ty - Ty dla mnie - jesteś Ja dla samego siebie, i podobnie Ja - Ja, który jestem Ja dla siebie - jestem dla ciebie Ty. Wiedza ta jest przyczółkiem, na którym można osadzić most między mną a tobą ${ }^{38}$.

36 Ks. R. Małecki, Komunijna prawda o człowieku, Kościele i świecie, [w:] Leksykon wielkich teologów XX i XXI wieku, red. J. Majewski, J. Makowski, Warszawa 2004, t. 2, s. 375 . Tekst ks. Małeckiego umieszczony jest w haśle „John Zizioulas”.

37 Por. M. Manikowski, „Być osobq̨” to „Być dla drugiego”: perspektywa teologii prawosławnej, [w:] Teologia bliźniego: obraz bliźniego a obraz Boga $w$ religiach monoteistycznych, red. W. Szczerba, M. Turowski, J. Zieliński, Białystok 2010, s. 133-141. W powyższych rozważaniach wykorzystuję swe myśli z tego właśnie tekstu.

38 J. Tischner, Filozofia dramatu, dz. cyt., s. 107, 111. 
Człowiek odrywa tę swoistą dialektykę będącą istotą tego, co określa się jako bycie człowiekiem - człowiek jest jednocześnie Ja dla siebie samego i Ty dla drugiego człowieka, a jednocześnie jest świadom, że drugi człowiek też jest Ja dla siebie samego i Ty dla drugiego człowieka, w tym i dla niego osobiście. Człowiek odkrywa tym samym, że jest osoba, nie tylko bytem w sensie metafizycznym, jednostkowym i niepowtarzalnym, tak jak większość bytów w rzeczywistości, ale że jest i bytem w sensie dialogicznym, czyli zawsze skierowanym ku innym. Tę prawdę człowiek odkrywa również analizując swą wiarę, która jest dla niego swoistym wychodzeniem $\mathrm{z}$ własnego Ja, $\mathrm{z}$ zapętlenia się $w$ sobie, by skierowywać się ku Boskiemu Ty, odkrywając jednocześnie, że w tym transcendowaniu swego Ja doświadcza nie tylko prawdy o sobie samym, ale również i prawdy o Bogu i swojej własnej wierze, jak również prawdy o drugim człowieku i jego wierze. Tym samym odkrywa wspólnotowość wiary.

\section{Wiara wspólnoty}

Odkrycie owej dialektyki Ja - Ty, odkrycie swego osobowego fundamentu prowadzi do zrozumienia ontologii ludzkiego bytu, będącego jednocześnie hipostazą i ekstazą, bytem zarazem jednostkowym i skierowanym ku innym. Człowiek nie potrafi więc inaczej funkcjonować w świecie, jak tylko będąc bytem, który wychodzi ku innym. I tak również powinien rozumieć swoją wiarę. Wiara będąca wykroczeniem, czy może: wykraczaniem, poza swoje Ja, jest jednocześnie wkroczeniem do wspólnoty, do komunii osób pojmowanej na wzór komunii Osób Trójcy Świętej (bo człowiek w swym początku stworzony został na obraz Boga, na obraz Trójcy Świętej). A to oznacza, że wiara będąca relacją człowieka z Bogiem jest równocześnie relacją człowieka z człowiekiem. Kardynał Joseph Ratzinger podkreśla: „Relacja z Bogiem jest zarazem relacją ludzką; opiera się na wspólnocie osób, co więcej, wspólna relacja z Bogiem umożliwia głębszą komunikację między ludźmi, która wykracza poza to, co korzystne, i dotyka centrum osoby" ${ }^{39}$. Relacja z Bogiem jest dla relacji z drugim 
człowiekiem w pewien sposób konstytutywna. Oczywiście, w ludzki byt wpisane jest bycie skierowanym ku innym, ale jest ono w niego wpisane, bowiem człowiek jako jedyny byt we wszechświecie został stworzony „na obraz i podobieństwo Boże”, czyli już na początku została w niego wpisana istotowa relacja człowieka do Boga, relacja bycia skierowanym ku swe$m u$ Stwórcy. Można zatem powiedzieć, że dopiero kiedy człowiek odkrywa swą relację do Boga, szczególnie w modlitwie, odkrywa też w sobie ową istotową relację ku drugiemu człowiekowi.

Tak tworzy się wspólnota wiary, tak tworzy się wspólna przestrzeń, wspólne - jak powiedziałby Józef Tischner - miejsce człowieka w świecie, bo tylko tam, gdzie człowiek spotyka drugiego człowieka, a także Boga, jest jego miejsce. Człowiek wzrasta w tej wspólnocie - wspólnota wzbogaca jego samego, a on sobą wzbogaca wspólnotę. Ale jednocześnie odkrywa to, co dla tego wzbogacania jest zasadnicze: konieczność ciągłego wybierania. Kiedy definiowałem wiarę jako odpowiedź na skierowane ku człowiekowi słowo, jako wybór, będący odpowiedzią na wybór, przywoływałem biblijne postacie Abrahama i Mojżesza. Warto teraz, w kontekście tego wszystkiego, co zostało dotąd powiedziane, dopowiedzieć coś naprawdę ważnego. Bóg kieruje do nas swe słowo $z a-$ wsze i na ten wybór mamy zawsze odpowiadać. Odpowiedź nie ma być jednorazowa, ale ciagła. Wiara nie jest jednorazowym aktem odpowiedzi na wezwanie, ale jest aktem nieustannie, codziennie powtarzanym i ponawianym. Bernhard Welte pisze:

Wiara codziennie musi powstawać na nowo, każdy dzień jest dla niej nowym dniem jej historii. Mimo to, albo raczej właśnie przez to, wiara może zachować i zachowa swą ciągłość. Na tym polega wierność, która z istoty swej przynależy do wiary ${ }^{40}$.

To nieustanne powtarzanie, to nieustanne wybieranie jest fundamentem wiary, gdyż poprzez to zyskuje ona nie tylko swą ciągłość, ale i to, co jest dla niej istotą: dynamiczność. Wiara nieodnawiana rychło staje 
się martwa, a taka wiara nie tylko nie ożywia człowieka, ale - przede wszystkim - nie ożywia wspólnoty. Tomáš Halík komentuje to tak:

Wiary oczywiście nie gubimy jak portmonetki; tylko pewnego dnia ze zdziwieniem stwierdzamy, że nasza wiara już dawno nie ma praktycznie żadnego wpływu na nasze życie i że nasza pobożność stopniowo i niepostrzeżenie uschła jak niepodlewany cyklamen $w$ doniczce za oknem ${ }^{41}$.

Niepodlewane kwiaty szybko usychają. Jest to doświadczenie, z którym spotykamy się bardzo często w życiu codziennym. Ono jednak uczy nas, że tak samo dzieje się w naszym życiu duchowym - wiara usycha, bo nie była podlewana naszym ciągłym jej wybieraniem, naszym ciągłym opowiadaniem się za Bogiem, ciągłym słuchaniem Jego wzywania, ale jednocześnie naszym ciągłym na to wezwanie odpowiadaniem. Do tego, by w tym wyzwaniu wytrwać, potrzeba nam cnoty cierpliwości: „Tak, również wiara, jeśli jest rzeczywiście wiarą, jest cierpliwa. Więcej: wiara jest cierpliwością"42.

Rozważania te można zakończyć słowami pochodzącymi z wiersza Jerzego Lieberta Jeździec, tak często przytaczanymi w kazaniach starosądeckich przez Józefa Tischnera i pokazującymi to, co dla rozumienia dialogicznego charakteru ludzkiej wiary jest fundamentalne, a co dla Josepha Ratzingera, Józefa Tischnera i Tomáša Halíka jest - by posłużyć się słowami tego ostatniego - cierpliwością wiary:

Jedno wiem i innych objawień

Nie potrzeba oczom i uszom -

Uczyniwszy na wieki wybór,

W każdej chwili wybierać muszę.

${ }_{41} \quad$ T. Halík, Drzewo ma jeszcze nadzieję, dz. cyt., s. 81.

42 Tenże, Cierpliwość wobec Boga, dz. cyt., s. 192. 